DOI https://doi.org/10.30525/978-9934-26-182-4-22

\title{
MARKERS OF AMNIOTIC MEMBRANES INFLAMMATION DURING PREGNANCY
}

\author{
Tsapenko T. V. \\ PhD, Bogomolets National Medical University, Obstetrics and gynecology \\ department, Assistant Professor, \\ Candidate of Medical Sciences, \\ Assistant Professor at the Department of Obstetrics and Gynecology № 1 \\ Bogomolets National Medical University \\ Kyiv, Ukraine
}

Premature rupture of amniotic membranes (PRAM) complicates about 10\% of all pregnancies, its frequency is highly dependent on gestational age. In premature pregnancy, the frequency of this complication reaches $50 \%$, in extremely premature pregnancy (up to 28 weeks) $-80 \%$. In this aspect, two questions still remain relevant: the reasons for rupture of the membranes before the onset of labor and the possibilities of preventing it [1,3], as well as the treatment strategy. Most guidelines recommend "watch and wait" tactics, which has different goals for term and preterm pregnancies. In a term of 37 weeks or more, the decision to postpone the induction of labor for 24 hours from the moment of rupture of the membranes is based on the likelihood of spontaneous onset of labor, which reaches $90 \%$. Until 37 weeks, "watch and wait" tactics purpose is to achieve the maximal fetal maturity, but should be implemented under the control of the inflammatory process markers with the use of antibacterial drugs of a wide spectrum of action $[2,4,5]$. The aim of the study is to evaluate the results of the glucose concentration in the amniotic fluid as an early marker of the inflammatory process in the membranes. We analyzed the course of pregnancy and childbirth in women with premature rupture of membranes at full-term depending on the amniotic concentration of glucose. "Watch and wait" tactics in case of premature rupture of amniotic membranes is preferable, while the leading criterion for the development of chorioamnionitis is clinical signs. It has been shown that in women with an amniotic glucose concentration during hospitalization less than $0.5 \mathrm{mmol} / 1$, hyperthermia is more often recorded before the onset of labor and during childbirth.

We examined 80 women with premature rupture of the amniotic membranes, who were hospitalized. The study included only those patients in whom no more than 6 hours passed from the moment of rupture of the amniotic 
membranes to hospitalization. In all patients, $3 \mathrm{ml}$ of amniotic fluid was taken with a sterile pipette, in which the glucose concentration was evaluated. Depending on the specific concentration of glucose and the gestational period of rupture of the membranes, the patients were divided into 4 groups. Groups I and II consisted of PRAM women at 24 weeks - 36 weeks and 6 days, in group I - 30 pregnant women with a glucose concentration in the amniotic fluid $>0,5$ $\mathrm{mmol} / \mathrm{l}$, in group II -10 pregnant women with $<5,0 \mathrm{mmol} / \mathrm{l}$. Group III and IV consisted of pregnant women with premature rupture of membranes at fullterm pregnancy (after 37 weeks), group III - 30 patients with amniotic glucose concentration $>0,5 \mathrm{mmol} / 1$, group IV - 10 pregnant women with $0,5 \mathrm{mmol} / 1$. In all groups, the further course of pregnancy was analyzed: the time that elapsed from rupture of the membranes to the onset of labor, the indications for induction of labor, hyperthermia before the onset of labor, deviations from the normal course of labor (hyperthermia, fetal distress during labor, weakness of labor), the frequency of the operative delivery. In addition, at the laboratory level, markers of the inflammatory process were studied (leukocytosis over $12 \times 10^{9} / 1$, C-reactive protein above $0,5 \mathrm{mg} / 1$ ). The results obtained were compared between the groups, and on the basis of the data obtained, the relative risk of hyperthermia and chorioamnionitis was calculated depending on the amniotic glucose content.

In all pregnant women with premature rupture of the membranes, body temperature is monitored as the first clinical marker of chorioamnionitis. It should be noted that the vast majority of cases of hyperthermia before the onset of labor in all groups were recorded within the first 12 hours from the moment of rupture of the membranes.

The data obtained allow us to conclude that a reduced concentration of glucose in the amniotic fluid is a sensitive criterion for the diagnosis of chorioamnionitis at the stage of hospitalization and the tactics choice for the treatment of patients with premature rupture of the amniotic membranes.

\section{CONCLUSIONS}

1. A decrease in the glucose concentration in the amniotic fluid less than 0,5 $\mathrm{mmol} / \mathrm{l}$ is associated with the more frequent and earlier clinical manifestation of chorioamninitis during the premature rupture of the amniotic membranes, both in full-term and premature pregnancies.

2. Evaluation of the glucose concentration in the amniotic fluid may be considered as an appropriate tool of preclinical diagnosis of chorioamnionitis for an individual choice of the treatment tactics for premature rupture of the membranes, which is especially important in premature pregnancy. 


\section{References:}

1. Венцківська І.Б., Страшко І.В., Венцківський К.О., Загородня О.С. Передчасний розрив плодових оболонок: нові генетичні чинники та можливий патогенез їхньої реалізації. Здоровье женщины. 2017. № 2. С. 26-29.

2. Венцковский Б.М., Загородняя А.С., Цапенко Т.В., Страшко И.В. Полиморфизм генов глутатион $\mathrm{S}$ - трансферазы - независимый фактор риска преждевременного разрыва плодных оболочек. Репродуктивное здоровье. Восточная Европа. 2015. №6 (42). С.8-14.

3. Kacerovsky M., Holeckova M., Stepan M., Gregor M., Vescicik P., Lesko D., Burckova H., Pliskova L., Bolehovska R., Andrys C., Musilova BoJ., Musilova I. (2020) Amniotic fluid glucose level in PPROM pregnancies: a glance at the old friend. The Journal of Maternal-Fetal\&Neonatal Medicine. DOI: 10.1080/14767058.2020.1783232

4. Leaños-Miranda A. Nolasco-Leaños A. G, Carrillo-Juárez R, I, MolinaPérez C. J, Isordia-Salas I, Ramírez-Valenzuela K. L. (2021) Interleukin-6 in Amniotic Fluid: A Reliable Marker for Adverse Outcomes in Women in Preterm Labor and Intact Membranes. Fetal Diagnosis and Therapy № 48, pp. 313-320. doi: 10.1159/000514898

5. PROM CPG Working Group. Association of Ontario Midwives. Management of Prelabour Rupture of Membranes at Term (2010). 